Lebedev, S.V. (2021). The problem of postmodern perception. Philosophical thought of the 21st century: if there is a future for philosophy. Collection of Scientific Articles. European Scientific e-Journal, 9 (15), 7-15. Hlučín: "Anisiia Tomanek" OSVČ.

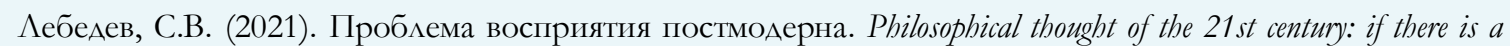
future for philosophy. Collection of Scientific Articles. European Scientific e-Journal, 9 (15), 7-15. Hlučín: "Anisiia Tomanek" OSVC.

DOI: $10.47451 /$ phi2021-10-002

The paper will be published in Crossref, ICI Copernicus, Academic Resource Index ResearchBib, J-Gate, ISI International Scientific Indexing, Zenodo, OpenAIRE, BASE, LORY, LUASA, ADL, eLibrary, and WebArchive databases.

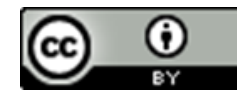

Sergey V. Lebedev, Full Professor, Dr of Philosophical Sciences, Head of the Department of philosophy, Higher School of Folk Arts (Academy). St. Petersburg, Russia.

ORCID: 0000-0002-7994-2660.

\title{
The problem of postmodern perception
}

Abstract: The concept of "postmodern" has turned from a philosophical term into a fashionable word, used incredibly widely by a variety of people under a variety of circumstances. As is often the case with popular words, it becomes difficult to give a concrete and generally accepted definition of what lies behind the concept of postmodernity. Postmodernism is also understood as the latest artistic and architectural trends. It seems that as many people as there are postmoderns. The study aimed to clarify the detection of postmodernism in philosophical thought based on the modern paradigm. In the study course, historical, comparative and logical methods were applied. To solve the research tasks, the works of leading modern specialists in postmodernism were used. The author concludes that the beginning of the $21 \mathrm{st}$ century will go down in history as a time of timelessness: no great ideas, no great feats, even no great crimes. On the other hand, Russia can take a leading place in the post-Western world if only it does not forget that it is a Eurasian country with its development path.

Kлючевъе слова: postmodernism, postmodern philosophy, multiculturalism, post-western era, deindustrialization.

Сергей Викторович Аебедев, профессор, Аоктор философских наук, заведующий кафеАры философии, Высшая школа народных искусств (Академия). Санкт-Петербург, Россия.

ORCID: 0000-0002-7994-2660.

\section{Проблема восприятия постмодерна}

Аннотачия: Понятие «постмодерн» из философского термина превратилось в модное слово, употребляемое невероятно широко самыми разными Аюдьми при самых разных обстоятельствах. Как это часто бывает с популярными словами, Аать конкретное и общепринятое определение того, что скрывается за понятием постмодерна, становится затруднительно. Под постмодерном понимают и новейшие художественные и архитектурные направления. Похоже, сколько мюдей, столько и постмодернов. Целью исследования яв ялось уточнение Аетекции постмодернизма в философской мысли исходя из современной парадигмы. В ходе исследования были применены исторический, сравнительный и могический методы. А^я решения поставленных задач исследования были использованы труды ведущих современных специалистов по постмодернизму. Автор приходит к выводу что начало XXI века войдет в историю как время 
безвременья: никаких великих идей, никаких великих подвигов, Ааже никаких великих преступлений. Россия же в пост-западном мире может занять ведущее место, если только не забудет, что явцяется евразийской страной, имеющей свой путь развития.

Keywords: постмодернизм, философия постмодерна, мультикультурализм, пост-западная эпоха, Аеиндустриализация.

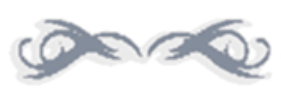

\section{Introduction}

The concept of "postmodern" has turned from a philosophical term into a fashionable word, used incredibly widely by a variety of people under a variety of circumstances. As is often the case with popular words, it becomes difficult to give a concrete and generally accepted definition of what lies behind the concept of postmodernity. Postmodernism is also understood as the latest artistic and architectural trends. It seems that as many people as there are postmoderns.

Common to various national variants of postmodernism can be considered its identification "with the name of the era of 'tired', 'entropic' culture, marked by eschatological moods, aesthetic mutations, diffusion of large styles, mixing of artistic languages. The avant-garde attitude to novelty is opposed here by the desire to include in modern art the entire experience of world artistic culture by its ironic quoting" (Science. Art. Greatness. Cultural Studies, 2020). (It would be better to directly call "ironic quoting" banter). "It is an intelligent procedure is more or less expanded rejection of the rationalist tradition of the Enlightenment, establishing independent of any empirical testing of theories, cognitive and cultural relativism which sees science as a 'narration' or social constructs among other" (Bricmont \& Sokal, 2002).

The study aims to clarify the detection of postmodernism in philosophical thought based on the modern paradigm.

The study tasks were:

- determine the relevance of the modern perception of postmodernism in the context of philosophical thought,

- trace the variability of the formation of the philosophical thought of postmodernism.

In the study course, historical, comparative and logical methods were applied.

To solve the research tasks, the works of leading modern specialists in postmodernism such as V. Bryson, J. Bricmont, N.E. Bulankina, M.Y. Chotchaeva, A.A. Khudin, C. Jencks, E.S. Maslova, M.A. Mozheiko, M. Onfray, V.T. Sosnovscky, N.A. Sheleshneva-Solodovnikova, N.V. Supron, E.S. Zolotova were used.

\section{Actualization of the modern postmodernism perception in the context of philosophical thought}

Unlike the predecessor of the modern era, when the culture was dominated by certain artistic styles, and now there is "multiculturalism", it has many genres, including (of course, only in theory), no dominant hegemony (Jencks, 1989). 
In the field of philosophy, postmodernism declares that now philosophy "in principle denies the possibility of reliability and objectivity, concepts such as 'justice' or 'righteousness' lose its value...” (Bryson, 2001).

Well, postmodern philosophy really does not pretend to discover great truths. It cannot and does not try to answer the classic questions: Who am I? From where? What can I know? What can I hope for? The philosophy of the postmodernists is occupied only "the game of beads" as G. Hesse said, i.e., intellectual games that do not give anything to either the mind or the heart. All fashionable postmodern words like "deconstruction", "simulacrum", "delegitimization", etc., cannot hide the fact that such a philosophy cannot explain this world and offer it a new transcendental idea. Accordingly, the postmodernist philosopher cannot offer any alternative to the current state of things. But it is precisely in the offer of an alternative that development is contained. The "removal" of contradiction means development. "Contradiction is the source of development," Hegel said. If philosophy admits that it not only cannot but is not going to "remove" the contradiction, then this is only the philosophy of sophists. And in fact, as sophists refused to seek the truth, referring to the subjectivity of perception of the world (recall Protagor's "man is the measure of all things!"), then postmodernists argue that we can only parse "texts" without any conclusions.

As the French philosopher, M. Onfray figuratively writes, "After what is now called the collapse of the great discourses - Christianity, Freudianism, Marxism, structuralism. Despite its own supposed death, philosophy has never felt so good. And, at the same time, she has never been so bad... Good, because it is constantly expected to make sense, answers to ethical and political, that is, existential questions: how to think, live and act without transcendental supports in a world subject only to the laws of the market? It's bad because responding to this general demand, supply allows mediocrity, traders, cynics and opportunists to push the next batch of contraband goods" (Onfray, 2012).

So, philosophy exists in the postmodern era but does not pretend to play the role of philosophy. Philosophy only reflects the thought of its society. As society is, so is philosophy.

To date, humanity has come to realize the exhaustion of the previous version of the world development in the absence of a clear understanding of what will replace it. It is no coincidence that nowadays when determining certain features of the state of the world, the prefix "post" is most often used. Western society is called post-industrial, post-class and post-national. Europe is considered a "post-Christian" continent. European integration, which largely deprived the EU countries of state sovereignty, led to the emergence of European "post-statehood". Russia and the former countries of the "socialist camp" are called post-socialist (which is absolutely fair, because it is impossible to call them capitalist and democratic, without lying to the soul). The absence of ideological alternatives is also manifested in the post-ideological nature of the modern world.

However, the word post is quite applicable to the current state of the science. Indeed, it can be said that the former "classical" scientific systems, born in the 19th century, can no longer claim to be able to explain all the features of the development of nature. The 19th century was the century of the creation of universal scientific systems. Newtonian physics, the periodic table, Darwin's theory, and finally Marx's philosophy and economic theory - all of them together offered a logical and convincing picture of nature and society. But for more than a century, this 
picture cannot be considered scientific. Modern physics cannot define matter or field. Similarly, medicine does not define life. Darwinism has little to offer to explain cloning.

But all this does not mean the appearance of more or less well-established alternative theories to the classics. In this sense, the era of "post classics" has really come in science now. And philosophy, as a result, also finds itself in a state of "postmodern".

So, in our time, the philosophical "postmodern" is just a statement of the fact that humanity has reached a dead end but, at the same time, does not know either the society in which it lives or how to find a way out of the impasse

\section{Variability of the formation of postmodernism philosophical thought}

It seems that the "post-era" should end soon. The world is dominated by Western powers, which cannot give humanity a great idea. Previously, the West for the non-Western (that is, most) part of humanity evoked associations with railways, steamships, newspapers, parliaments, Christianity, universities. Now Western values are reduced to "big macs" and the rights of sexual minorities. The rise of religious fundamentalism in these conditions is quite understandable. And this only means that the half-thousand-year domination of Western civilization is coming to an end. In the 21st century, countries such as China, India, Brazil, Nigeria, and some other countries of the recent political and economic periphery will play a leading role.

Well, and the West itself? He is entering the post-Western era. Nowadays, the West is already quite different compared to the 1950s and 60s, when they started talking about postmodernism. The low birth rate and high life expectancy led to the fact that Western nations began to turn into nations of pensioners. At the same time, it should understand that even the younger generation of current Europeans and white Americans is the "generation of only children". The infantile, who grew up in abundance, brought up by TV in the countries of the victorious sexual revolution, is hardly capable of decisive and deliberate actions.

Weakened by hedonism, Westerners lose the ability to fight. It is especially significant to military service. The death of one soldier during a peacekeeping mission causes immediate hysteria with the demand to "return the boys" home. And 2021 witnessed the shameful flight of Americans from Afghanistan. And this means that the West is no more. Instead, there is only a certain number of States in which there is a certain political regime and a certain social system. There are no nations in the West either. There is only a collection of various minorities.

Until recently, it was the West (along with the USSR) based on world industrial and scientific and technological development. However, that is in the past now. Nowadays, real production is concentrated in China and other countries of the "South". The West itself has become only a consumer. When beginning all this globalization the West hoped goods would be produced somewhere in the East or South and consumed in the West. But these beliefs were based on sand. Of course, sooner or later, those countries and territories that produce goods will require an appropriate share of global distribution.

The withdrawal of industry to countries with cheap labour has led to the large-scale deindustrialization of the West. A kind of symbol of this deindustrialization was an anecdotal case when George W. Bush, upon learning that the star-spangled flag sewn in China was proudly flying over the White House, ordered to find a real flag sewn in America. Oddly enough, there is still a bit of light industry left in this country, and the national flag sewn on the territory of the 
United States managed to be found. Only illegal immigrants from Asia worked at the factory where it was sewn.

The election of US President Barack Hussein Obama has become a classic example of how a country leaving the scene chooses a young barbarian as its leader. It was the case in the Roman Empire during the decline. Then the emperors were natives of remote provinces and, later, natives of the barbarian periphery. In the United States, where various racial minorities already make up the majority of the population, only a representative of an old minority that is completely rooted in the country can become president, unlike, e.g., Latinos.

The bulk of workers in the countries of the modern West are no longer workers, but office workers. The incredibly expanded service sector provides the bulk of the GNP of Western countries. However, the real sector of the economy, which creates material values, is increasingly shrinking. Only strategic considerations explain the fact that the military industry of Western countries has not yet been transferred to Asia or Latin America. However, all these circumstances make it very difficult to get out of the crisis by expanding domestic demand, as recommended by Keynes' theory and as Roosevelt's America emerged from the Great Depression.

In the 1960s, G. Marcuse and other thinkers of the "new left" pinned all their hopes on the student youth, like racial, ethnic and other minorities, as a force capable of changing the world. However, after the 1968 events, the ruling Western establishment managed to turn the revolt of system outsiders into a game. The authorities in power have successfully applied:

- $\quad$ artization, i.e., the withdrawal of protest into the plane of show business, pop art, etc.;

- $\quad$ anaesthesia, i.e., the protest withdrawal from the real world into the world of dreams;

- religification, i.e., the planting of various mystical cults among the protesters, which was supposed to switch interests from changing reality to questions of "afterlife";

- carnivalization, i.e., imposing the idea of political activity as a game, entertainment, holiday, which, naturally, turns this activity into politically safe.

Street demonstrations turned into flash mobs. The authorities have launched work to create a "youth ghetto", to encourage, invent and plant youth subcultures. At the same time, tolerance and multiculturalism began to be imposed - to ensure inner peace, to avoid the repetition of mass demonstrations of minorities. At the same time, the education "reform" started in the West when education primitivizing and profanation began to be introduced under the guise of "democratization". As a result, a whole generation of people has already grown up in the West, intelligent and educated in their way, excellent narrow specialists, but having a very mosaic, devoid of integrity, idea of the world and humanity. Philosophy by definition is not suitable for the masses' primitivizing. Therefore, it should be reduced to a set of disparate esoteric texts.

So, the grapes of anger did not bloom, and society began to exist, not burdened with great ideals, but for a long time free from shocks.

All this had a very direct impact on philosophy. If earlier J.-P. Sartre proclaimed that an intellectual cannot but be engaged, now political engagement for a philosopher becomes a bad tone.

In politics, the postmodern era has led to sad results, undermining the intellectual level not only of system opponents but also the established ones. 
Political leaders of the postmodern era are made with the help of television and social networks. Nowadays, it is unlikely that F.D. Roosevelt, who, as you know, rode in a wheelchair, became president. However, a charmer like Macron, who looks good on a blue screen, devoid of other qualities, and becomes the leader of the nation. However, this is the political elite of modern Europe.

\section{Conclusion}

The beginning of the 21 st century will go down in history as a time of timelessness: no significant ideas, no great deeds, not even any great crimes.

Until recently, great ideologies dominated the world, offering alternatives to the existing order of things. Now there are no clear ideological alternatives in sight. Various environmental, feminist and anti-globalist organizations do not pretend to create global positive theories. And these are not the ideas for which you can give your life.

What is happening in the world is sad. Western civilization with all its countless disadvantages still provided a phenomenal rise of humanity. Now, the African and Oriental traditions that will dominate the world of the new century are unlikely to be able to ensure its further development. It seems that the fall of Western civilization will resemble a similar fall of the ancient world, replaced by the "dark ages".

On the other hand, Russia can take a leading place in the post-Western world, if only it does not forget that it is a Eurasian country with its own path of development.

However, there are opportunities to avoid the new Middle Ages. Humanity must move to a kind of "neo-modern". It is necessary to discard the current Western model of development, as it has become a dead-end, and return to the origins of development. If it wants to remain philosophy, it is necessary to return to dialectics in the philosophy field.

It is necessary to recall and critically evaluate the philosophical achievements of Western dialectics, e.g., the Frankfurt School, G. Marcuse, J.-P. Sartre, E. Gellner, E. Hobsbaum, N. Chomsky, I. Wallerstein, A. Negri, S. Zizek. Let us recall the achievements of Russian philosophy, which is not limited to idealists from the former Marxists of the "silver age". From the Russian philosophical thought, it is necessary to turn first of all to the work of the Slavophiles who justified the difference between Russian civilization and the Western Romano-Germanic one. We must recall the inspiring thoughts of Russian cosmists again if we want to give society, and the whole world as a whole, a fascinating idea.

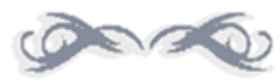

\section{References:}

Bricmont, J., \& Sokal, A. (2002). Intellectual tricks. Criticism of modern postmodern philosophy. Moscow: The House of Intellectual Books. (in Russian)

Bryson, V. (2001). The political theory of feminism. Moscow: Idea-Press. (in Russian)

Bulankina, N.E. (2020). Comprehensive model of humanitarian self-organisation of personality in the era of post-modernism. Psychology of Education in a Multicultural Space, 3 (51), 42-49. Yelets State University named after I.A. Bunin. (in Russian) 
Chotchaeva, M.Y., \& Sosnovscky, V.T. (2017). Postmodernism in modern culture and literature. Bulletin of the Adygea State University. Series 2: Philology and Art History, 2 (197), 177-182. Maikop: Adygea State University. (in Russian)

Jencks, C. (1989). What is post-modernism. NY.

Khudin, A.A. (2018). On duality in the architecture of postmodernism. Modern Architecture of the World, 11, 39-54. Moscow: Central Research \& Design Institute. (in Russian)

Maslova, E.S. (2018). The erosion of identity in postmodernism. Humanities of the South of Russia, 7, 6, 105-111. Federal Research Sociological Center of the Russian Academy of Sciences, Southern Federal University. (in Russian)

Mozheiko, M.A. (2018). Modern socio-cultural transformations and the latest trends in philosophy: from postmodernism to post-postmodernism. Man, Society, History, Language, Culture in Modern Scientific Consideration. Materials of the International Scientific Conference, 65-81. (in Russian)

Onfray, M. (2012). L'ordre Libertaire: La vie philosophique de Albert Camus. Flammarion. (in French)

Science. Art. Greatness. Cultural Studies (2020, August 27). Retrieved October 5, 2021, from http://culture.niv.ru/doc/aesthetic/lexicon/220.htm (in Russian)

Supron, N.V. (2020). A look at the problem of values in the era of postmodernism. Epoch of Science, 22, 296-299. Krasnoyarsk State Agrarian University. (in Russian)

Zolotova, E.S. (2015). Postmodernism: from culture to anti-culture. Philosophy of Economy, 2 (98), 276-297. Moscow: Investment company "Barrel”. (in Russian) 